\title{
Karakterisasi Bakteri Genus Vibrio Dari Ikan Kerapu (Plectropomus sp.)
}

\author{
AR. SYARIF HIDAYAT \\ Jurusan Biologi, Fakultas Sains dan Teknologi, UIN Alauddin Makassar \\ Jl. Sultan Alauddin 36 Samata, Kab. Gowa 92113 \\ email: syarifhidayat@uin-alauddin.ac.id
}

\begin{abstract}
This research is about the isolation and characterization Vibrio sp. from grouper fish (Plectropomus sp.). This research aimed to observe the amount of vibrio bacteria species based on colony morphology and characterization morphological colony of vibrio isolated from grouper fish (Plectropomus sp.). Bacteria isolation was conducted by isolate some external organs (lesion on its body) and internal organ (jejenum) from grouper fish (Plectropomus sp.). Bacteria was grown on selective medium for vibrio, TCBS (Thiosulfate Citrate Bile Sucrose) agar. The incubation time was 24 hours at $37^{\circ} \mathrm{C}$. The result showed there are 3 isolate vibrio bacteria that was coded by V1, V2, and V3. V1 morphological characteristis was rounded, edge is entire, convex elevation, green colony colour with blue in the center of colony and smooth tekstur. V2 morphological characteristic was rounded, edge is entire, tortous elevation, colony colour yellow, and smooth tekstur. Morphological characteristic of V3 was Irregular, egde is Undulate, elevation hill, colony colour yellow and own the smooth tekstur.
\end{abstract}

Keywords: characterization, grouper fish (Plectropomus sp.), isolation, Vibrio

\section{PENDAHULUAN}

Peranan budidaya pantai dewasa ini semakin meningkat sejalan dengan besarnya potensi pengembangannya baik sumber daya lahan maupun jenis komoditas. Ikan kerapu tersebar luas di perairan pantai baik di daerah tropis maupun sub tropis, dan termasuk jenis ikan yang hidup di perairan berkarang sehingga sering dikenal sebagai ikan karang (coral reef fish). Beberapa jenis ikan kerapu yang banyak terdapat di Indonesia sebagai komoditi andalan untuk dibudidayakan antara lain ikan kerapu bebek atau tikus (Cromileptes altivelis), kerapu macan (Epinephelus maculatus), kerapu sunu (Plectropomus leopardus), kerapu lumpur (Epinephelus coioides), kerapu malabar (Epinephelus malabaricus), dan kerapu bintik atau batik (Epinephelus bleekeri). Ikan kerapu selain memiliki nilai jual yang tinggi juga dalam proses produksinya lebih banyak memanfaatkan sumber daya laut yang ada baik dengan menggunakan kapal dalam proses penangkapan ataupun yang dibudidayakan (Aslianti, 2006). Kerapu sunu (P. leopardus) merupakan komoditas ekspor yang harganya cukup tinggi. Dua jenis ikan kerapu yang berharga tinggi dan terdapat di Indonesia yaitu
Plectropomus leopardus (Leopard corraltrout) dan Plectropomus maculatus (Barred cheek corral trout). Harga jenis Leopardus hidup dilaporkan mencapai $\mathrm{Rp} 60.000,00$ per $\mathrm{kg}$ (Sudradjat, 2008).

Penyakit infeksi bakteri gram negatif merupakan penyakit utama pada kerapu (Plectropomus $s p$ ). Gejala akibat serangan penyakit ini, diantaranya ikan tidak mau makan dan lemah, berenang di permukaan, menyendiri, serta adanya luka di permukaan tubuh. Bakteri genus Vibrio dapat menyebabkan penyakit pada ikan kerapu sunu, seperti pembusukan pada sirip, borok pada bagian tubuh dan mulut merah. Penyakit selalu muncul sebagai proses dinamis akibat tidak seimbangnya hubungan antara inang (host), jasad penyakit (patogen), serta lingkungan (Sarono et al. 1993). Adanya kecenderungan Vibrio dalam menyerang ikan kerapu (Plectropomus sp.), maka penulis tertarik untuk melakukan penelitian dengan judul karakterisasi bakteri Vibrio dari ikan kerapu (Plectropomus sp.).

\section{METODE}

Jenis Penelitian. Jenis penelitian ini menggunakan metode observational deskriptif 
dengan melakukan isolasi dan karakterisasi bakteri genus Vibrio pada ikan kerapu (Plectropomus sp).

Populasi dan Sampel. Sampel penelitian yaitu ikan kerapu (Plectropomus sp.) yang kemudian dibedah secara aseptis untuk mengambil kulit (borok pada badan) dan organ usus.

Isolasi dan Identifikasi Bakteri Vibrio sp. Organ badan dan usus ikan yang telah diambil direndam ke dalam cawan petri yang sebelumnya telah diisi dengan larutan PBS (Phosphate Buffer Saline), Setelah 10 menit kemudian dikeringkan di atas kertas saring. Masing-masing organ digerus dan dikultur dengan media Alkali Peptone Water (APW) diinkubasi suhu $37^{\circ} \mathrm{C}$ selama 6-8 jam dilanjutkan dengan penanaman di media Thiosulfate Citrate Bile Salt Sucrose (TCBS) yang inkubasi pada suhu $37^{\circ} \mathrm{C}$ selama 24 jam. Pengamatan yang dilakukan secara morfologi antara lain: pengamatan bentuk sel, warna koloni, ukuran koloni dan tipe koloni, elevasi, dan tekstur koloni.

\section{HASIL}

Hasil isolasi dan karakterisasi bakteri Vibrio dari ikan kerapu (Plectropomus sp.) pada organ kulit (borok pada badan) dan organ usus, dapat dilihat pada tabel 1 dan 2 .

Tabel 1. Keberadaan koloni bakteri Vibrio pada organ yang diisolasi

\begin{tabular}{llll} 
No & Kode Isolat & \multicolumn{2}{c}{ Koloni Bakteri Pada Organ } \\
\cline { 3 - 4 } & & \multicolumn{2}{c}{ Badan } \\
2 & V1 & Ada & Tidak ada \\
3 & V2 & Tidak ada & Ada \\
V3 & Tidak ada & Ada \\
\hline
\end{tabular}

Tabel 2. Karakteristik morfologi koloni bakteri Vibrio yang diisolasi dari ikan kerapu sunu (P. leopardus).

\begin{tabular}{cccccc}
$\begin{array}{c}\text { Kode } \\
\text { isolat }\end{array}$ & \multicolumn{4}{c}{ Karakteristik Koloni Pada Lempeng Agar Medium TCBS Agar } \\
\cline { 2 - 5 } & Bentuk & Tepi & Elevasi & Warna & Tekstur \\
V1 & Bulat & Rata & Mencembung & $\begin{array}{c}\text { Hijau, biru pada } \\
\text { tengah koloni }\end{array}$ & Halus \\
& & & Kuning & Halus \\
V2 & Bulat & Rata & Melengkung & Kuning & Halus \\
V3 & Tak beraturan & Berombak & Membukit & Kol
\end{tabular}

\section{PEMBAHASAN}

Ikan kerapu sunu (Plectropomus $s p$ ) yang digunakan untuk penelitian adalah ikan yang terlihat adanya gejala serangan dari bakterial. Hasil isolasi bakteri Vibrio $s p$ dari ikan kerapu (Plectropomus $s p$ ) yang diisolasi pada badan dan usus ditemukan tiga isolat bakteri Vibrio yang diberi kode isolat dengan V1, V2 dan V3. Isolat V1 ditemukan di organ badan, sedangkan pada organ usus tidak ditemukan. Isolat V2 ditemukan di organ usus tetapi tidak ditemukan di organ badan. Sedangkan untuk isolat V3 ditemukan di organ usus namun tidak ditemukan pada organ badan. Hasil karakterisasi dan identifikasi dari ke tiga isolat
(V1, V2, dan V3) adalah sebagai berikut: Isolat V1. Berdasarkan hasil dari karakteristik morfologi koloni bakteri, isolat V1 memiliki bentuk bulat dengan tepi yang rata, elevasi (bentuk permukaan koloni) mencembung, berwarna hijau dan pada tengah koloni berwarna biru serta memiliki tekstur yang halus. Koloni V1 berwarna hijau pada media TCBS karena sangat jarang memfermentasi sukrosa sehingga warna koloni nampak berwarna hijau. Ikan kerapu yang terserang bakteri Vibrio memberikan gejala penurunan nafsu makannya, lethargi (gelisah/kesadaran ikan menurun), pembusukan sirip, popeye (mata bengkak atau menonjol yang biasanya 
menyebabkan kebutaan), dan akumulasi cairan di bagian abdomen. Isolat V2. Berdasarkan hasil dari Karakteristik morfologi koloni bakteri, isolat V2 memiliki bentuk bulat dengan tepi yang rata, elevasi (bentuk permukaan koloni) melengkung, berwarna kuning dengan tekstur yang halus. Koloni V2 berwarna kuning pada media TCBS terjadi ketika bakteri tersebut memfermentasi sukrosa menjadi asam.

Penyakit yang disebabkan oleh Vibrio pada manusia misalnya adalah gastroenteritis yang disebabkan oleh produk hasil laut, terutama yang dimakan mentah, dimasak tidak sempurna atau terkontaminasi dengan seafood mentah setelah pemasakan. Isolat V3. Berdasarkan karakteristik morfologi koloni bakteri, isolat V3 memiliki bentuk tak beraturan tepi yang berombak, elevasi (bentuk permukaan koloni) membukit, berwarna kuning dengan tekstur yang halus. Koloni V3 berwarna kuning pada media TCBS terjadi ketika bakteri tersebut memfermentasi sukrosa menjadi asam (Fardiaz, 1983).

\section{KESIMPULAN}

Dari hasil penelitian didapat bahwa pada ikan kerapu (Plectropomus sp.) yang telah diisolasi ditemukan adanya 3 jenis isolat berdasarkan morfologi koloni yang berbeda, yang masing-masing diberi kode isolat dengan V1, V2, dan V3.

Karakterisasi dari ketiga isolat adalah V1: bentuk bulat dengan tepi yang rata, elevasi (bentuk permukaan koloni) mencembung, berwarna hijau dan pada tengah koloni berwarna biru serta memiliki tekstur yang halus, V2: bentuk bulat dengan tepi yang rata, elevasi (bentuk permukaan koloni) melengkung, berwarna kuning dengan tekstur yang halus, V3: bentuk tak beraturan tepi yang berombak, elevasi (bentuk permukaan koloni) membukit, berwarna kuning dengan tekstur yang halus.

\section{DAFTAR PUSTAKA}

Ali A. 2005. Mikrobiologi Dasar. Jilid 1. Cet. 1. Makassar: Universitas Negeri Makassar Press.

Aslianti. 2006. Pemeliharaan Larva ikan Kerapu, Dengan Padat Tebar yang Berbeda. Jakarta: Jurnal penelitian perikanan Indonesia. vol 1:1.

Austin B and Austin DA. 2007. Bacterial and Fish Pathogens: Disease Farmed and Wild Fish. Germany: Praxis Publishing.

Campbell, Neil A, Reece, Jane B, Mitchell, Lawrence G. 2003. Biology. $5^{\text {th }}$ ed. California: Department of Botany and Plant Science University of California Riverside.

De Paola A, Kaysner CA, and John B. 1998. Enviromental Investigation of Vibrio parahaemolitycus in Oyster After Outbreakes in Washington, Texas and New York. New York pub.

Fardiaz S. 1993. Keamanan Pangan. Jilid 1. Bogor: Fakultas Teknologi Pertanian Jurusan Ilmu dan teknologi Pangan, Institut Pertanian Bogor.

Pelczar MJ, dan Chan ECS. 1986. Dasar-dasar Mikrobiologi 1. Jakarta: Universitas Indonesia Press.

Murtidjo BA. 2002. Budi Daya Kerapu Dalam Tambak. Cet. 5: Yogyakarta: Penerbit Kanisus.

Sarono A, Widodo, dan Haryani EBS. 1993. Deskripsi Hama dan penyakit Ikan Karantina Golongan Bakteri. Edisi kedua. Yogyakarta: Pusat karantina Pertanian dan Fakultas Pertanian Jurusan Perikanan Universitas Gadjah Mada.

Sudradjat A. 2008. Budi daya 23 Komodititas Laut Menguntungkan. Cet. 1. Jakarta: Penebar Swadaya.

Yuasa dkk. 2003. Panduan Diagnosa Penyakit Ikan. Balai Budidaya Air Tawar. Jambi: Ditjen Perikanan Budidaya, DKP dan JICA. 